University of Nebraska - Lincoln

DigitalCommons@University of Nebraska - Lincoln

Papers in the Earth and Atmospheric Sciences

Earth and Atmospheric Sciences, Department

\title{
Combined use of frequency-domain electromagnetic and electrical resistivity surveys to delineate near-lake groundwater flow in the semi-arid Nebraska Sand Hills, USA
}

\author{
John T. Ong \\ University of Nebraska-Lincoln, jbong@huskers.unl.edu \\ John W. Lane Jr. \\ U.S. Geological Survey \\ Vitaly A. Zlotnik \\ University of Nebraska-Lincoln, vzlotnik1@unl.edu \\ Todd Halihan \\ Oklahoma State University - Main Campus \\ Eric A. White \\ U.S. Geological Survey
}

Follow this and additional works at: https://digitalcommons.unl.edu/geosciencefacpub

Part of the Earth Sciences Commons

Ong, John T.; Lane, John W. Jr.; Zlotnik, Vitaly A.; Halihan, Todd; and White, Eric A., "Combined use of frequency-domain electromagnetic and electrical resistivity surveys to delineate near-lake groundwater flow in the semi-arid Nebraska Sand Hills, USA" (2010). Papers in the Earth and Atmospheric Sciences. 277.

https://digitalcommons.unl.edu/geosciencefacpub/277

This Article is brought to you for free and open access by the Earth and Atmospheric Sciences, Department of at DigitalCommons@University of Nebraska - Lincoln. It has been accepted for inclusion in Papers in the Earth and Atmospheric Sciences by an authorized administrator of DigitalCommons@University of Nebraska - Lincoln. 


\section{Combined use of frequency-domain electromagnetic and electrical resistivity surveys to delineate near-lake groundwater flow in the semi-arid Nebraska Sand Hills, USA}

John B. Ong • John W. Lane, Jr. • Vitaly A. Zlotnik • Todd Halihan • Eric A. White

\begin{abstract}
A frequency-domain electromagnetic (FDEM) survey can be used to select locations for the more quantitative and labor-intensive electrical resistivity surveys. The FDEM survey rapidly characterized the groundwaterflow directions and configured the saline plumes caused by evaporation from several groundwater-dominated lakes in the Nebraska Sand Hills, USA. The FDEM instrument was mounted on a fiberglass cart and towed by an all-terrain vehicle, covering about $25 \mathrm{~km} /$ day. Around the saline lakes, areas with high electrical conductivity are consistent with the regional and local groundwater flow directions. The efficacy of this geophysical approach is attributed to: the high contrast in electrical conductivity between various groundwater zones; the shallow location of the saline zones; minimal cultural interference; and relative homogeneity of the aquifer materials.
\end{abstract}

Keywords Frequency-domain electromagnetic · Electrical resistivity · Geophysical methods - Field techniques . Salt-water/fresh-water relations · USA

Received: 11 September 2009 / Accepted: 17 May 2010

(C) Springer-Verlag 2010

J. B. Ong $(\bullet) \cdot$ V. A. Zlotnik

Department of Geosciences,

University of Nebraska-Lincoln,

214 Bessey Hall, Lincoln, NE 68588, USA

e-mail: jbong@huskers.unl.edu

Tel.: +1-402-4722663

Fax: +1-402-4724917

J. W. Lane, Jr • E. A. White

Office of Groundwater,

Branch of Geophysics, US Geological Survey,

11 Sherman Place, Unit 5015, Storrs Mansfield, CT 06269, USA

T. Halihan

School of Geology,

Oklahoma State University,

105 Noble Research Center, Stillwater, OK 74078, USA

\section{Introduction}

In large areas of the US, complex lake-groundwater interactions are important and must be thoroughly evaluated to assess the sustainability of water resources and ecology. Determining the orientation, distribution, and scale of fluxes in the vicinity of natural surface water bodies is very labor-intensive, requiring the coverage and extensive sampling of large areas. New approaches to infer fluxes include cases when groundwater and surface water differ in temperatures or isotopic composition (e.g., Lowry et al. 2007; Walker and Krabbenhoft 1998). These approaches, however, require invasive sampling or sensor deployment at various depths.

Recent advances in data interpretation and electronics have made it possible to use electromagnetic (EM) and electrical resistivity (ER) surveys to delineate groundwater interfaces non-invasively, especially in areas of seawater intrusion (Fitterman and Deszcz-Pan 1998; Day-Lewis et al. 2006) and groundwater salinization (Bauer et al. 2006). In arid and semi-arid environments, the salinity of groundwater-dominated lakes is increased when surface evaporation exceeds precipitation (Wood and Sanford 1990). In Fig. $1, Q_{\text {in }}$ is the inflow rate of fresh groundwater with concentration $C_{\text {in }}$ and $Q_{\text {out }}$ is the outflow rate with elevated concentration $C_{\text {out }}$. Lake water of elevated salinity discharges into a groundwater system and moves downgradient with the ambient flow (Townley and Trefry 2000; Zlotnik et al. 2009), interacting with it to produce a saline plume. This approach was tested in the Nebraska Sand Hills, Nebraska, USA.

The Nebraska Sand Hills (Fig. 2), the largest vegetated dune field in the Western Hemisphere, covers $58,000 \mathrm{~km}^{2}$. Very active during the Holocene (Mason et al. 2004), the dune field is now stabilized by vegetation. Precipitation is about $30 \mathrm{~cm} /$ year in the west, increasing eastward to $50 \mathrm{~cm} /$ year. Recharge is on the order of $2.5 \mathrm{~cm} /$ year (Wilhite and Hubbard 1990). During the Pleistocene, recharge into the highly permeable dunes raised the groundwater levels in the High Plains aquifer, producing numerous interdunal lakes. Currently, 1,500 to 2,500 topographic depressions hold perennial lakes (Rundquist 1983) with total dissolved solids (TDS) ranging from 


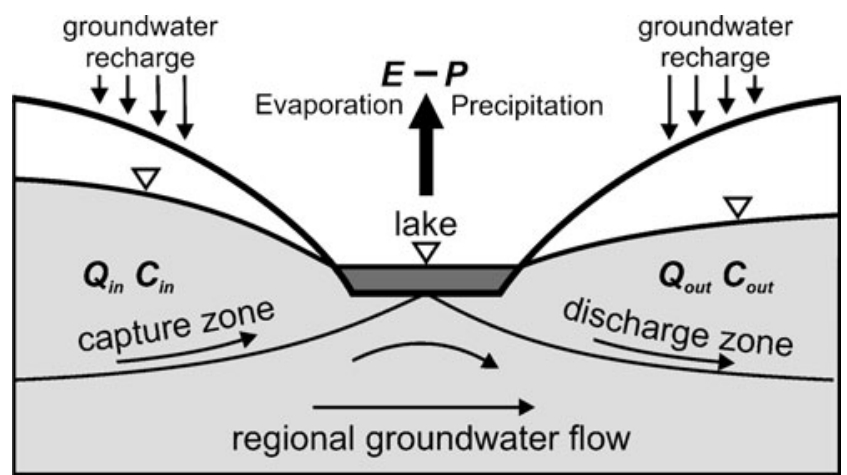

Fig. 1 Lake water as a natural tracer in a flow-through system. $Q_{i n}$ is the inflow rate of fresh groundwater with concentration $C_{i n}$ and $Q_{\text {out }}$ is the outflow rate with elevated concentration $C_{\text {out }}$

$0.3 \mathrm{~g} / \mathrm{L}$ (freshwater) to hypersaline values $>100 \mathrm{~g} / \mathrm{L}$ (McCarraher 1977; Gosselin 1997), typically higher than the groundwater TDS of 0.13-1.7 g/L (Zlotnik et al. 2007).

The study area is located on the margins of the dune field where late Pleistocene and middle Holocene migrating dunes blocked two large paleovalley systems, raising the water table and creating over a thousand interdunal lakes (Fig. 2). Fresher, flow-through lakes are located above the dune dam where the hydraulic gradient is steep, whereas saline, gaining lakes occur far from the discharge point of a buried paleovalley, identified by Loope et al. (1995) from core $\operatorname{logs}$ and radiocarbon dating, along which the hydraulic gradient is gentle. Aside from regional climate, other factors that control lake salinity include the topographic and hydrological position of the lakes within the regional groundwater system (Townley and Trefry 2000; Zlotnik et al. 2009) and eolian transport of salt (Ong et al. 2009).

The high contrast in electrical conductivity (EC) between saltwater plumes and freshwater aquifers, low population density (fewer than 2 persons per $\mathrm{km}^{2}$ ) and well-sorted, fine-to-medium grain size of the dune sands (Sweeney and Loope 2001), make the Nebraska Sand Hills an ideal site for testing the use of ER surveys supplemented by the frequency-domain electromagnetic (FDEM) technique to delineate saltwater plumes surrounded by fresh groundwater. Several freshwater and saline lakes (Fig. 2) were surveyed using this method.

\section{Methods}

The EC of earth materials is affected by various factors, including porosity, water content, salinity, temperature, soil texture, and mineralogy. FDEM-induction instruments measure subsurface apparent EC without galvanic contact using alternating electromagnetic fields to induce subsurface eddy currents (Ward and Hohmann 1988). This nonintrusive approach enables rapid mapping of conductive subsurface structures (Callegary et al. 2007) and has been used for various near-surface applications including aquifer properties assessment (Schneider and Kruse 2003), delineation of contaminated groundwater plumes (Lanz et al. 1998), and estimation of soil saturation and salinity (Sheets and Hendrickx 1995; Paine 2003).

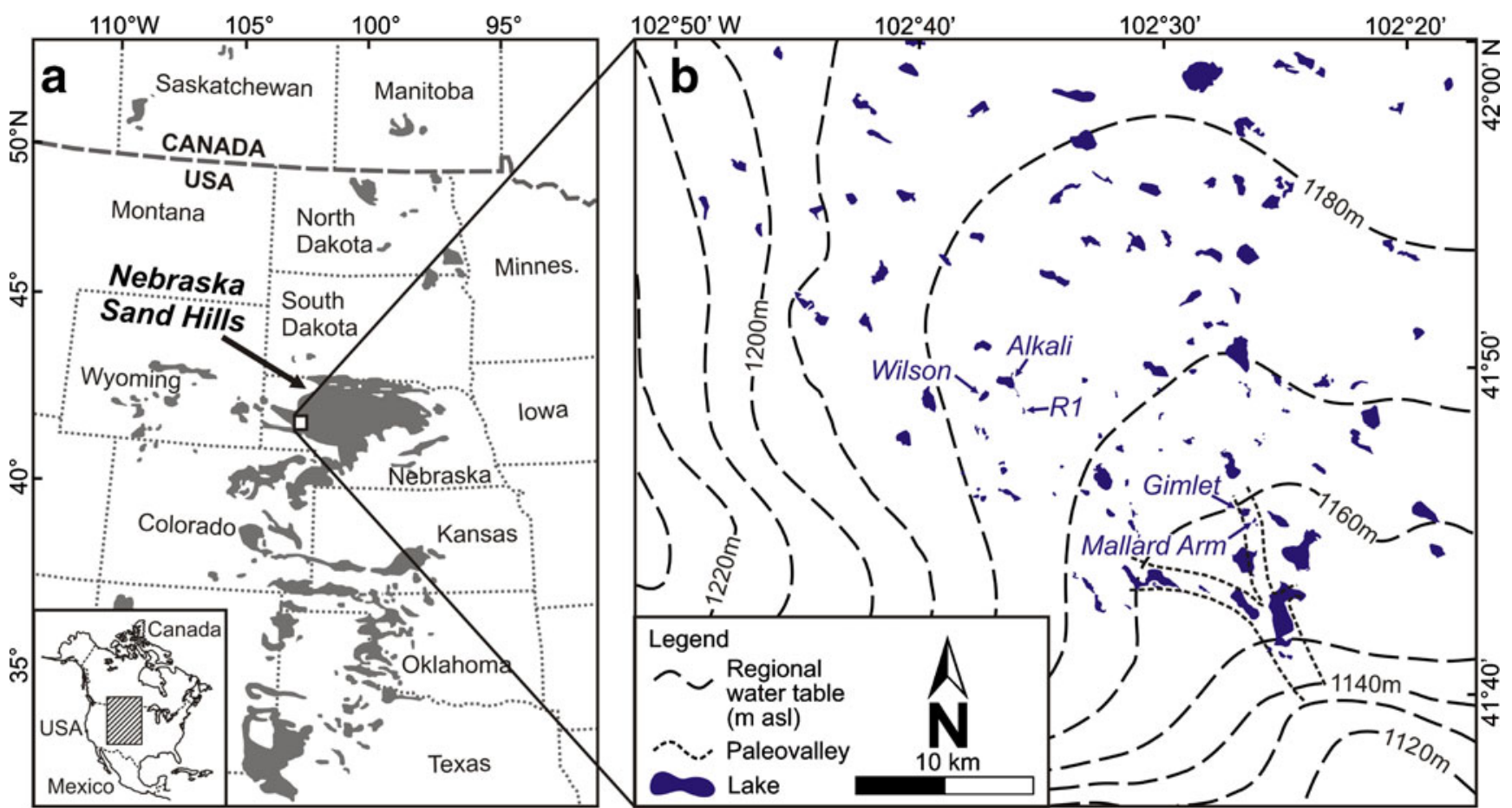

Fig. 2 a Stabilized dune fields in the Great Plains of North America are shown in black (modified from Foreman et al. 2001); dotted lines are state boundaries. b The lakes studied in Garden County, Nebraska Sand Hills, include Alkali, Wilson, Gimlet, Mallard Arm and an unnamed one labeled Rl. Regional groundwater flow (University of Nebraska-Lincoln, 2008) shows steeper gradients along the paleovalley mapped by Loope et al. (1995) 
FDEM-induction instruments typically contain three coils: transmitter, receiver, and bucking. The transmitter coil produces the primary magnetic field that induces eddy currents in a conductive earth. A bucking coil is used to remove the primary field from the receiving coil because the secondary magnetic field, produced by the induced eddy currents, is extremely small (Won 2003). Depth of penetration of EM fields into the subsurface involves many factors (Huang 2005), but its maximum is quantified by a useful surrogate, the skin depth, $\delta$ :

$$
\delta=\frac{1}{\sqrt{\pi \mu \sigma f}}
$$

where $\mu$ is magnetic permeability, $\sigma$ is $\mathrm{EC}$, and $f$ is frequency in homogeneous systems. Equation 1 indicates that skin depth increases with decreasing frequency and EC. For most earth materials, $\mu$ is assumed to be constant and equivalent to $\mu_{0}$, the value for free-space. Assuming a relatively homogenous subsurface, EC correlates positively with TDS in water and skin depth is inversely proportional to the average groundwater salinity. Obtaining skin depths $\delta_{1}$ and $\delta_{2}$ at two frequencies, $f_{1}$ and $f_{2}$, yields the ratio $\delta_{1} / \delta_{2}$ that can be used to infer vertical salinity distribution (Huang 2005).

A modified GEM-2 manufactured by Geophex, Ltd. was used (note, any use of trade, product, or firm names is for descriptive purposes only and does not imply endorsement by the authors). Similar to the original GEM-2 described by Won et al. (1996), this tool measures apparent electrical conductivity but can transmit up to 55 frequencies from about 1 to $63 \mathrm{kHz}$. Rather than multiplexing, the modified unit sequentially steps through a set of user-specified frequencies. As the instrument is moved along a survey line, it collects data over the user-selected frequency range. Each sweep of stepped-frequency measurements takes about $1 \mathrm{~s}$. Apparent conductivity profiles for each frequency can be generated. In addition, under the right conditions, it has been shown that the multifrequency FDEM data can be interpreted as depth soundings (Abraham et al. 2006).

In contrast to non-contact FDEM methods, directcurrent ER methods induce current into the subsurface by injecting current between two electrodes in direct contact with the earth. One of the oldest geophysical methods, ER imaging has been used for many applications, including delineation of the freshwater/saltwater interface (Nassir et al. 2000; Goldman and Kafri 2006), monitoring plumes of groundwater contamination (Cassiani et al. 2006; Webb et al. 2008), locating fractures in solid host rocks (Seaton and
Burbey 2002), and differentiating sandy aquifers from clays (Baines et al. 2002).

\section{Data collection}

In August 2007 and May 2008, the geophysical surveys were conducted around three saline lakes, Alkali, Wilson, and R1 and two freshwater lakes, Gimlet and Mallard Arm (Fig. 2). All five lakes are less than $1.5 \mathrm{~m}$ deep. Table 1 lists lake surface areas computed from topographic maps (USGS $1986 \mathrm{a}, \mathrm{b}, \mathrm{c})$ and electrical properties of the lake waters measured in 2007 and 2008. Lake TDS was estimated using regression between groundwater EC and TDS, after Zlotnik et al. (2007). Typical freshwater salinity values are less than $1 \mathrm{~g} / \mathrm{L}$, whereas average seawater is $35 \mathrm{~g} / \mathrm{L}$.

The FDEM surveys were used to identify apparent conductivity anomalies to be investigated with the more quantitative and time-consuming ER surveys. Data were collected for 15 transmitted frequencies linearly spaced from 0.3 to $96 \mathrm{kHz}$, a band chosen because it provides usable low frequencies with depth of penetrations on the order of tens of meters (Paine and Minty 2005) and high frequencies, which tend to provide improved lateral resolution. The GEM-2 was mounted on a fiberglass cart at a standard survey height of $1 \mathrm{~m}$ and towed near the shoreline by an all-terrain vehicle (ATV) at a speed of approximately $1.2 \mathrm{~m} / \mathrm{s}$ around each lake (Fig. 3). A commercial-grade global positioning system (GPS; Trimble PRO XRS) continuously recorded positions. Abraham et al. (2006) reported that typical drift rates for the GEM-2 are very small for short-term measurement times such as the 1.5 hours it took to survey the longest lake perimeter, and so it was not necessary to collect instrument drift data during these surveys intended for reconnaissance purposes only.

Two different ER instruments were used at different stages of the study. An automated 8-channel resistivity meter, the SuperSting R8/IP ${ }^{\mathrm{T}}$ (Advanced Geosciences, Inc), was used to measure apparent resistivities around the saline lakes (Fig. 3). The system had 56 electrodes spaced 5, 8, 9, or $10 \mathrm{~m}$ apart in a dipole-dipole configuration. The elevation of each electrode was measured using a real-time kinematic geodetic-grade differential GPS (Topcon Hyperlite). In addition, a DZD-6A single-channel resistivity unit manufactured by Beijing Orangelamp Co. and a manual switch box were used to measure apparent resistivities around the freshwater lakes. Each survey employed 48 electrodes spaced $5 \mathrm{~m}$ apart in a Wenner configuration. Multiple readings to quantify errors were not practical with the use of a manual switch box. To ensure good data quality,

Table 1 Lake surface area and electrical properties of lake water

\begin{tabular}{lcccc}
\hline Lake & Surface area (ha) & Electrical conductivity $(\mathrm{mS} / \mathrm{m})$ & Electrical resistivity $(\mathrm{ohm}-\mathrm{m})$ & TDS $(\mathrm{g} / \mathrm{L})$ \\
\hline Alkali & 50.3 & $5,700-12,170$ & $0.2-0.1$ & $38.1-81.4$ \\
Wilson & 19.2 & $1,034-1,796$ & 0.6 & $0.9-12.0$ \\
R1 & 4.4 & $2,800-13,010$ & 0.1 & $18.7-87.0$ \\
Gimlet & 24.5 & $74-84$ & $6.5-11.9$ \\
Mallard Arm & 6.7 & 162 & 6.2 & 1.1 \\
\hline
\end{tabular}



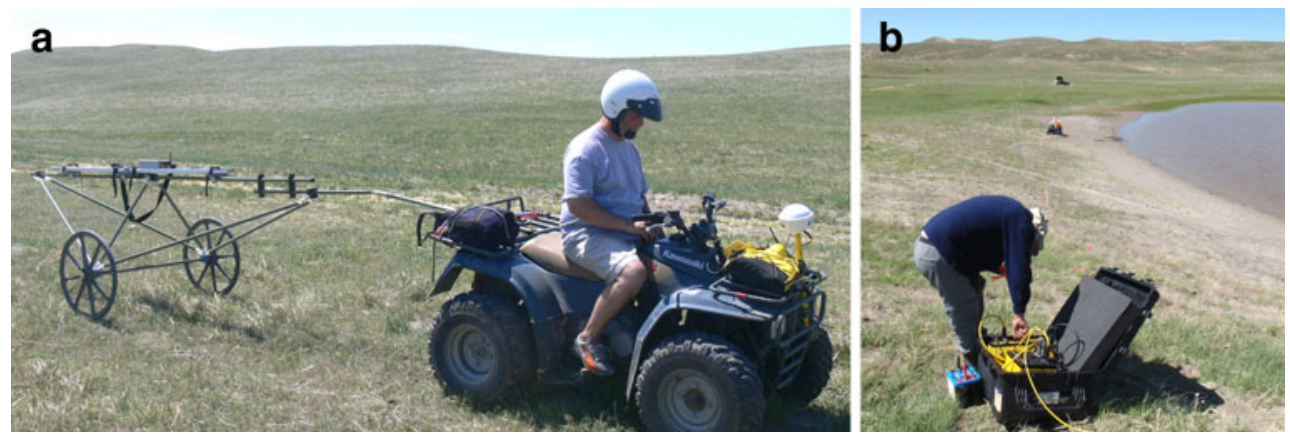

Fig. 3 Field instrumentation: a the GEM-2 is mounted on a fiberglass cart and pulled by an all-terrain vehicle (ATV); the GPS is mounted on the front of the ATV. $\mathbf{b}$ the eight-channel resistivity unit and switch box

apparent resistivities were plotted in the field after each survey and values that were obviously too large or too small compared to the neighboring data points were re-measured. The relative elevation of each survey line was measured using a total station, model NTS302R +(Orangelamp Co). Apparent resistivities gathered from both saline and freshwater lakes were inverted using the AGI EarthImager 2D software (version 1.9.0).

\section{Results}

At least $25 \mathrm{~km}$ of towed EM data were collected each day. Spatial plots of average EC over all frequencies are shown in Fig. 4, in which high EC values indicate more saline groundwater. Average EC around the saline lakes ranged from 10 to $150 \mathrm{mS} / \mathrm{m}$. Values of EC greater than $100 \mathrm{mS} / \mathrm{m}$ cluster along the eastern and southeastern shores. Average EC around the freshwater lakes is about a third of that measured around the saline lakes and higher EM values define a NE-SE axis congruent with the paleochannel axis previously mapped by Loope et al. (1995). The presence of a segment with elevated salinity downstream from the lakes is consistent with regional and local groundwater flow directions and with the hypothesized presence of capture and discharge zones around lakes in semi-arid conditions.

$\mathrm{EC}$ at low and high frequencies were compared to infer changes in $\mathrm{EC}$ as a function of depth under the assumption that lower frequencies penetrate deeper than higher frequencies. EC values at $11,610 \mathrm{~Hz}$ had the least noise and were chosen for the lower frequency; $63,030 \mathrm{~Hz}$ was used for the high frequency. $\mathrm{EM}_{11,610 \mathrm{~Hz}} / \mathrm{EM}_{63,030 \mathrm{~Hz}}$ conductivity ratios of about 1 indicate that $\mathrm{EC}$ is uniform with depth. Ratio greater and less than 1 may respectively indicate that EC and salinity increase and decrease with depth. Plots of the ratios as a function of location were compared to resistivity profiles (Figs. 5 and 6). Results of EM and ER are presented as conductivity and resistivity, respectively, the hotter colors indicating higher resistivity and lower conductivity values.
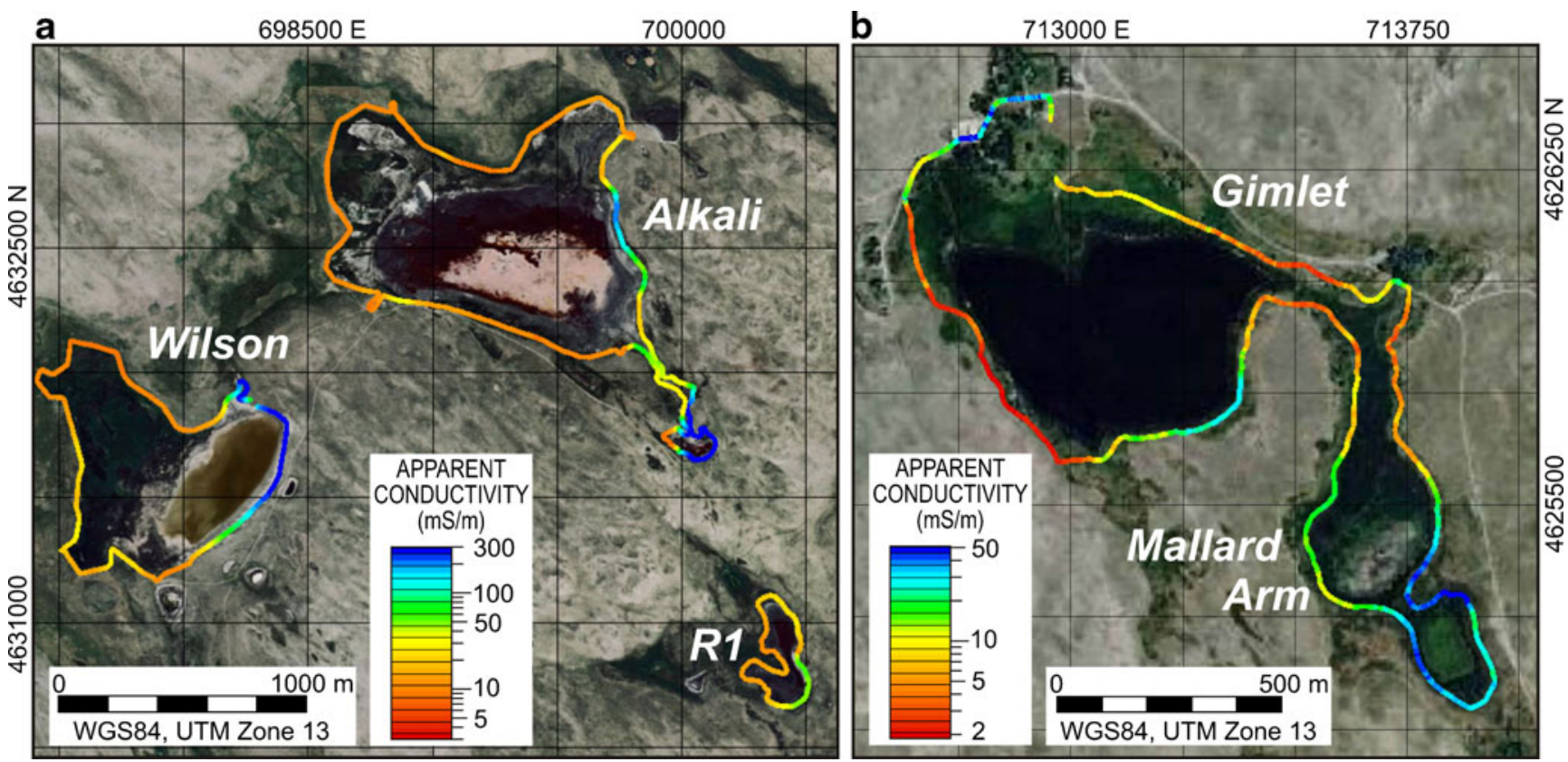

Fig. 4 Average subsurface electrical conductivities around a saline and b freshwater lakes in Garden County, Nebraska Sand Hills. Note different linear and apparent conductivity scales on the two plots. Base map from Farm Service Agency, USDA 2007, photograph taken 27 June 2006 

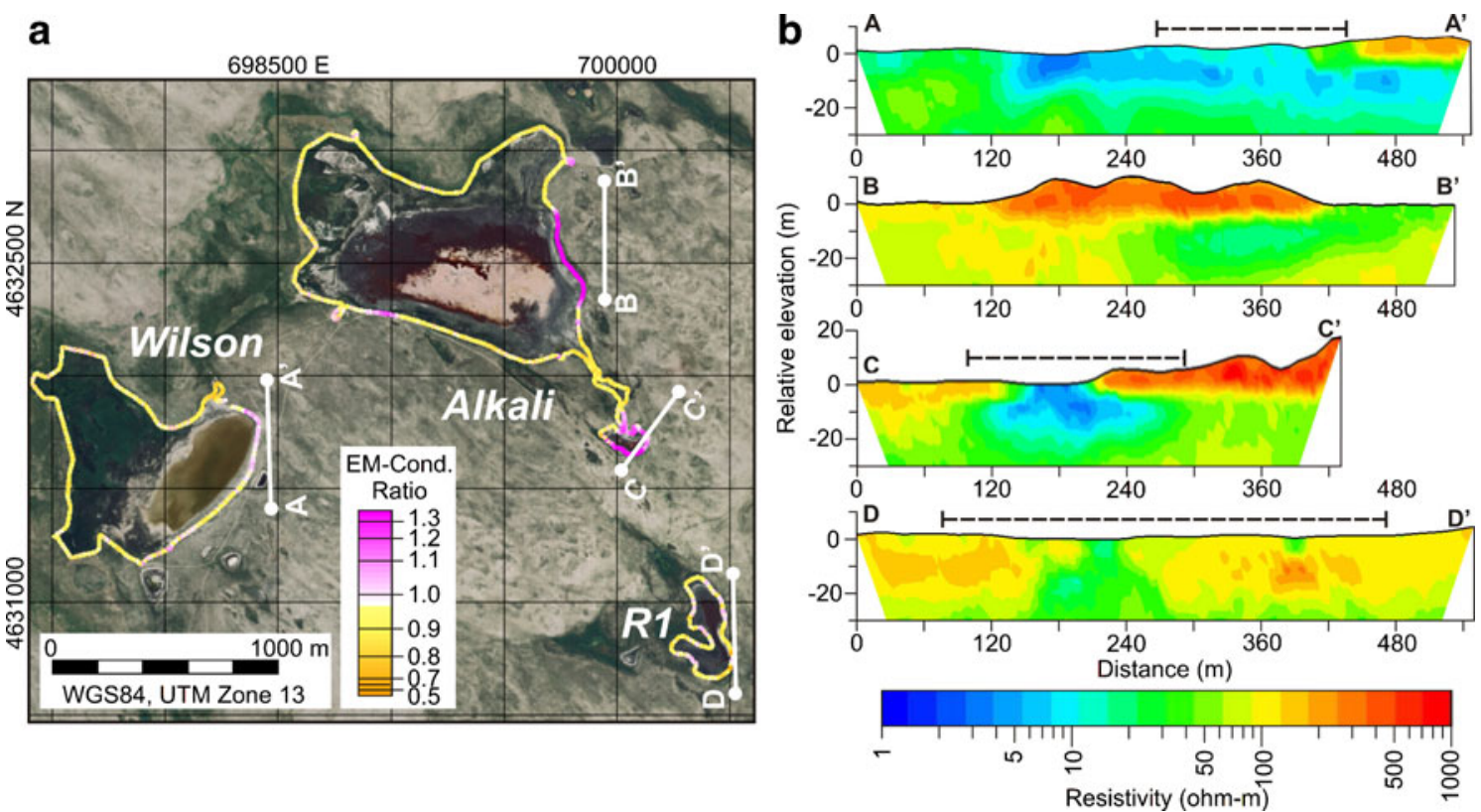

Fig. 5 a Map of $\mathrm{EM}_{11,160 \mathrm{~Hz}} / \mathrm{EM}_{63,030 \mathrm{~Hz}}$ conductivity ratios around the saline lakes in Garden County, Nebraska Sand Hills (base map from Farm Service Agency, USDA 2007, photograph taken 27 June 2006); color scale displayed in a Gaussian distribution. b Inverse modeling results of electrical resistivity (ER) profiles. Dashed lines represent segments where ER and EM data overlap

Most of the EM conductivity ratios around the saline lakes are between 0.7 and 0.9 , indicating less EC with depth. Ratios greater than 1.3 were found on the eastern and southeastern sides of Alkali and Wilson Lakes. On the east side of Lake R1, ratios ranged from 0.7 to 1.1 , whereas southwest of Alkali Lake, they were between 0.9 and 1.1 .

To determine the configuration of the inferred saline plumes, ER surveys were conducted on the eastern sides of the saline lakes where EC values were anomalously high. Inversion of ER data collected near the saline lakes required 3-8 iterations and had root mean square (RMS) errors of $4-7 \%$. Forward modeling and sensitivity analysis indicate that the patchy distribution in resistivity is an inversion artifact due to juxtaposed high resistivity values from dunes and low resistivity values from saline shores and plumes. Dashed lines in Fig. 5 indicate segments where the ER profiles roughly coincide with the EM plots. The decrease in resistivity from $300 \mathrm{ohm}-\mathrm{m}$ at the dune surface to less than $100 \mathrm{ohm}-\mathrm{m}$ at elevations of about $-10 \mathrm{~m}$ along survey lines $\mathrm{AA}^{\prime}, \mathrm{BB}^{\prime}$, and $\mathrm{CC}^{\prime}$ is consistent with the high EM conductivity ratios $>1.3$, which indicate that EC increases with depth. On the southeast sides of
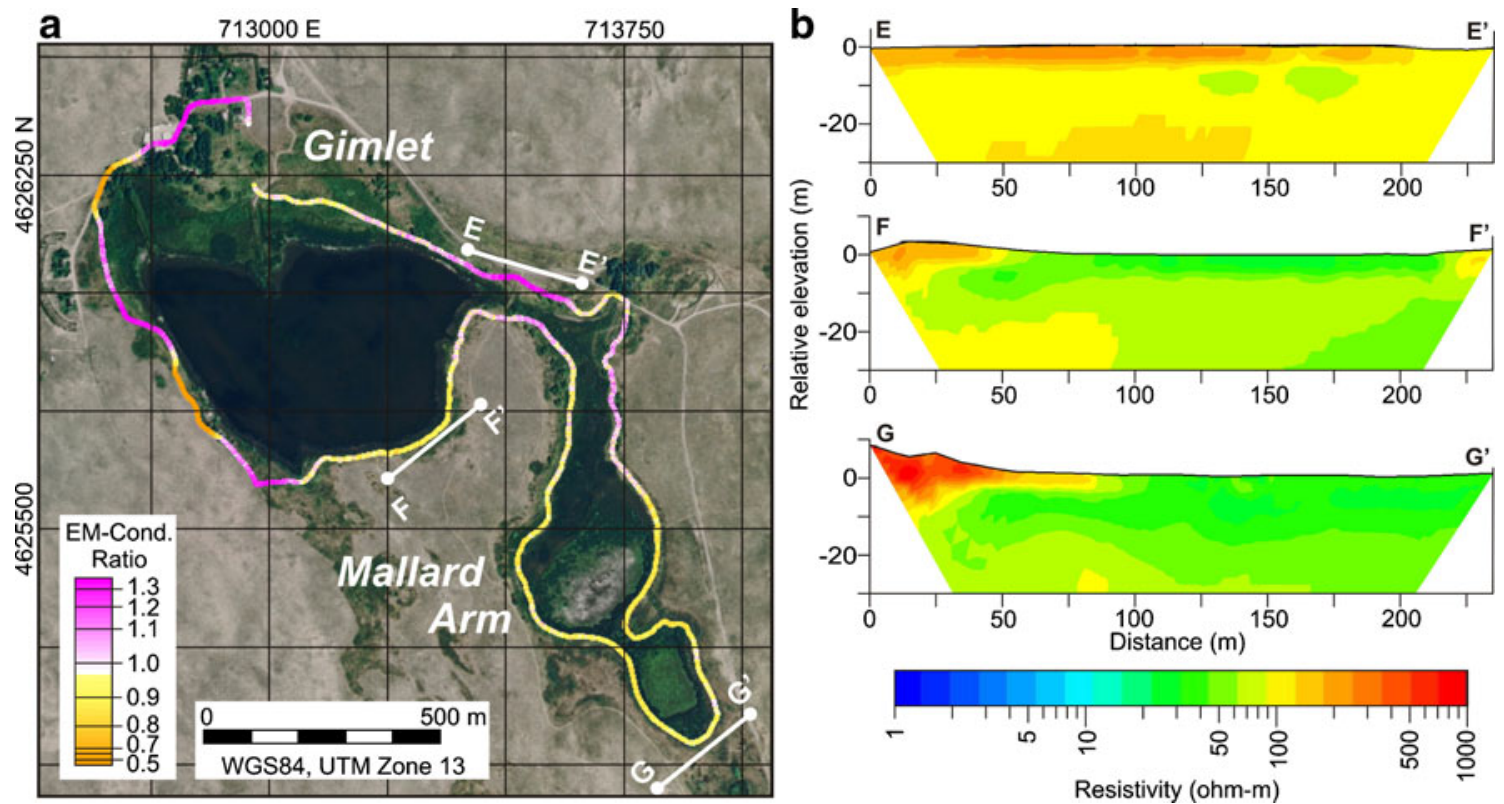

Fig. 6 a Map of $\mathrm{EM}_{11,160 \mathrm{~Hz}} / \mathrm{EM}_{63,030 \mathrm{~Hz}}$ conductivity ratios around the freshwater lakes in Garden County, Nebraska Sand Hills (base map from Farm Service Agency, USDA 2007, photograph taken 27 June 2006); color scale displayed in a Gaussian distribution. b Inverse modeling results of electrical resistivity profiles 
Wilson and Alkali Lakes, EM conductivity ratios are closer to 1, and the ER profiles, $\mathrm{AA}^{\prime}$ and $\mathrm{CC}^{\prime}$, show uniformly low resistivities. East of Lake R1, EM conductivity ratios are close to 1 but show some variability. Likewise, ER line DD' does not show strong contrast in resistivity with depth for depths of 0 to $-10 \mathrm{~m}$.

For the freshwater lakes, two ER survey lines were selected in areas with high EC anomalies and one line with low EC anomaly (Fig. 6). The ER surveys were at an elevation closer to the lake and had RMS errors of less than $2 \%$. The EM conductivity ratio near EE' is greater than 1 and the ER profile shows a fairly uniform resistivity distribution with a more resistive layer over more conductive material. Near ER lines FF' and GG', the EM conductivity ratio is 0.7 to 0.9 , which indicates lower EC with depth. This pattern is consistent with the increase in ER values downward below the 20 to $30 \mathrm{ohm}-\mathrm{m}$ level in the upper $5 \mathrm{~m}$ of the profile.

\section{Discussion}

EC anomalies at the eastern and southern sides of the saline lakes may be due to saline plume-associated flow from the saline lakes down the regional groundwater gradient (Fig. 2; also see Olaguera 2007, p. 63 Fig. 3-15). Horizontal head gradients on the order of $0.1 \%$ move the saline plumes toward the eastern to southeastern side of the lakes. Vertical convective flow of saline plumes such as those geophysically documented in the Okavango delta in Botswana (Bauer et al. 2006) and Arabian sabkha (Van Dam et al. 2009), were not observed in these lakes. Average EC values around the freshwater lakes were only a third of those measured around the saline lakes. A northwest-southeast trending axis of relatively high EC anomalies in this freshwater environment is attributed to the presence of fine sediments, because EC increases with decreasing grain size (Aristodemou and Thomas-Betts 2000). The trend of EC anomalies coincides with the axis of the paleovalley in Fig. 2 identified by Loope et al. (1995). In some cases, traces of elevated groundwater salinity occur upgradient from the lakes.

On the plots of average EC around the lakes, areas of high average EC correspond to areas of high EM conductivity ratios $(>1.3)$ around the saline lakes; areas of high average EC correspond to lower ratios (0.7-0.9) around the freshwater lakes. EM conductivity ratios $>1.3$, which indicate an increase in EC with depth, are interpreted as unsaturated dune sand overlying saline groundwater at distances of $400-450 \mathrm{~m}$ in $\mathrm{AA}^{\prime}$ and 210 $280 \mathrm{~m}$ in CC'. In BB', to the east of Alkali Lake, unsaturated dunes overlie fresh groundwater. As the inferred near-surface salinities increase closer to Wilson Lake and southeast of Alkali Lake, the conductivity ratio approaches unity (290-400 $\mathrm{m}$ in AA' and $140-210 \mathrm{~m}$ in CC'). Further southwest on line CC', from 80 to $140 \mathrm{~m}$, the increase in EM conductivity ratio $(>1.3)$ is interpreted as freshwater overlying saline groundwater. Around the freshwater lakes, lower EM conductivity ratios $(0.7-0.9)$ along the axis of the paleovalley, in FF' and GG', are interpreted as indicating an increase in grain size with depth.

\section{Conclusions}

An FDEM survey is an efficient reconnaissance method for mapping EM ground conductivities to guide subsequent and more detailed ER surveys. Use of an ATV for towing the GEM-2 enhanced the efficiency of the reconnaissance survey, allowing more than $25 \mathrm{~km}$ of EC profiles to be collected daily. For the saline lakes, high EC anomalies are clustered on the eastern and southeastern shores, consistent with the direction of regional groundwater flow. For the freshwater lakes, EC anomalies coincide with the axis of a paleovalley. Average EC simply shows clustering of high EC anomalies on the shores of both freshwater and saline lakes, but the ratios of the EM conductivities were used successfully to discriminate between increasing or decreasing EC with depth patterns.

Resistivities from inversion of the ER profile data are consistent and complementary to the conductivities measured in the EM surveys. The combined and sequential use of the FDEM and resistivity methods proved effective for initial characterization of subsurface EC for this study site. The GEM-2-identified conductive zones around the lakes that were targeted for further investigation with the resistivity methods. Although the GEM-2 methods could estimate the shallow distribution of EC, the resistivity method penetrated deeper into the aquifer. The efficacy of this geophysical approach is attributed to: (1) noticeable contrast in electrical conductivity between freshwater and saltwater, (2) near-surface location of the freshwater/saltwater interface (depth of less than $20 \mathrm{~m}$ ), (3) minimum cultural interference, and (4) relative homogeneity of the aquifer materials.

Acknowledgements This project was funded by NSF (ER0609982), the US Geological Survey Groundwater Resources and Toxic Substances Hydrology Programs, and Yatkola-Edwards research grant from the Nebraska Geological Society. Modification of the GEM-2 was performed under the auspices of a CRADA between Geophex, Ltd. and the USGS. The authors thank N. Powers and M. French (the Crescent Lake National Wildlife Refuge) for assisting with the study logistics and H. Yonkin (Rex Ranch) for access to Alkali Lake. K. Thompson (Oklahoma State Univ.), A. Ramadan (Desert Research Center, Cairo, Egypt), and Y. Leventeli (Akdeniz University, Turkey) assisted in conducting the ER surveys. We are grateful to C.B. Dawson, J.B. Callegary, and C.D. Johnson (all from the USGS), K.S. Rodolfo (Univ. of IllinoisChicago), R. Supper (Univ. Calabria, Italy), P. Bauer-Gottwein (Tech. Univ., Denmark), and P. Brunner (Flinders Univ., Australia) for reviewing this report.

\section{References}

Abraham JD, Deszcz-Pan M, Fitterman DV, Burton BL (2006) Use of a handheld broadband EM induction system for deriving resistivity depth images. In: Gamey J (ed) 19th Annual Symposium on the Application of Geophysics to Engineering 
and Environmental Problems. Seattle, Washington, April 2006, pp 1782-1799

Aristodemou E, Thomas-Betts A (2000) DC resistivity and induced polarization investigations at a waste disposal site and its environments. J Appl Geophys 44:275-302

Baines D, Smith DG, Froese DG, Bauman P, Nimeck G (2002) Electrical resistivity ground imaging (ERGI): a new tool for mapping the lithology and geometry of channel-belts and valley-fills. Sedimentology 49:441-449

Bauer P, Supper R, Zimmermann S, Kinzelbach W (2006) Geoelectrical imaging of groundwater salinization in the Okavango Delta, Botswana. J Appl Geophys 60:126-141

Callegary JB, Ferré TPA, Groom RW (2007) Vertical spatial sensitivity and exploration depth of low-induction-number electromagnetic-induction instruments. Vadose Zone J 6:158-167

Cassiani G, Bruno V, Villa V, Fusi N, Binley A (2006) A saline trace test monitored via time-lapse surface electrical resistivity tomography. J Appl Geophys 59:244-259

Day-Lewis FD, White EA, Johnson CD, Lane JW Jr (2006) Continuous resistivity profiling to delineate submarine groundwater discharge: examples and limitations. Leading Edge 25 (6):724-728

Farm Service Agency, USDA (2007) FSA 2006-Digital Ortho Mosaic-1 Meter-Index for the State of Nebraska, images4110212, 4110213, 4110221. USDA, Washington DC. http://dnr.ne.gov/CoqArea/coq06/coqutm/41102/. Cited 2 Dec 2009

Fitterman DV, Deszcz-Pan M (1998) Helicopter EM mapping of saltwater intrusion in Everglades National Park, Florida. Explor Geophys 29:240-243

Foreman SL, Oglesby R, Webb RS (2001) Temporal and spatial patterns of Holocene dune activity on the Great Plains of North America: megadroughts and climate links. Global Planet Change 29:1-29

Goldman M, Kafri U (2006) Hydrogeophysical application in coastal aquifers. In: Vereecken H, Binley A, Cassiani G, Revil A, Titov K (eds) Applied hydrogeophysics. Springer, Amsterdam, pp 233-254

Gosselin DC (1997) Major-ion chemistry of compositionally diverse lakes, western Nebraska, U.S.A.: implications for paleoclimatic interperetations. J Paleolimnol 17:33-49

Huang H (2005) Depth of investigation for small broadband electromagnetic sensors. Geophys 70(6):G135-G142

Lanz E, Green A, Boerner DE, Maurer H (1998) Landfill delineation and characterization using electrical, electromagnetic and magnetic methods. J Environ Eng Geophys 3(4):185-196

Loope DB, Swinehart JB, Mason JP (1995) Dune-dammed paleovalleys of the Nebraska Sand Hills: intrinsic versus climatic controls on the accumulation of lake and marsh sediments. GSA Bull 107(4):396-406

Lowry CS, Walker JF, Hunt R, Anderson MP (2007) Identifying spatial variability of groundwater discharge in a wetland stream using a distributed temperature sensor. Water Resour Res 43: W10408. doi:10.1029/2007WR006145

Mason JA, Swinehart JB, Goble RJ, Loope DB (2004) LateHolocene dune activity linked to hydrological drought, Nebraska Sand Hills, USA. The Holocene 14(2):209-217

McCarraher DB (1977) Nebraska's Sandhills lakes. Nebraska Game and Parks Comission, Lincoln, NB, 67pp

Nassir SSA, Loke MH, Lee CY, Nawawi MNM (2000) Saltwater intrusion mapping by geoelectrical imaging surveys. Geophys Prospecting 48:647-661

Olaguera F (2007) Investigating flow-through regimes of the Sandhills lakes. Master Thesis, Univ. Nebraska-Lincoln, USA, $107 \mathrm{pp}$

Ong JB, Zlotnik VA, Swinehart JB, Schmieder J, Fritz SC (2009) Salt distribution around Alkali Lake, Nebraska Sand Hills, U.S. A. Geol Soc Am Abstracts with Programs 41(7):445

Paine JG (2003) Determining salinization extent, identifying salinity sources, and estimating chloride mass using surface, borehole, and airborne electromagnetic induction methods. Water Resour Res 39(3):3-1-3-10. doi:10.1029/2001WR000710

Paine JG, Minty BRS (2005) Airborne hydrogeophysics. In: Rubin Y, Hubbard S (eds) hydrogeophysics. Springer, Amsterdam, pp 333-357

Rundquist DC (1983) Wetland inventories of Nebraska's Sandhills: resource report. Publ. 9, Univ. Nebraska-Lincoln, Conservation and Survey Division, $46 \mathrm{pp}$

Schneider JC, Kruse SE (2003) A comparison of controls on freshwater lens morphology of small carbonate and siliciclastic islands: examples from barrier islands in Florida, USA. J Hydrol 284:253-269

Seaton W, Burbey TJ (2002) Evaluation of two-dimensional resistivity methods in a fractured crystalline-rock terrane. J Appl Geophys 51:21-41

Sheets KR, Hendrickx JMH (1995) Noninvasive soil water content measurement using electromagnetic induction. Water Resour Res 31(10):2401-2409

Sweeney MR, Loope DB (2001) Holocene dune-sourced alluvial fans in the Nebraska Sand Hills. Geomorphology 38(1-2):31-46

Townley LR, Trefry MG (2000) Surface water-groundwater interaction near shallow circular lakes: flow geometry in three dimensions. Water Resour Res 36(4):935-948

United States Geological Survey (1986a), Crescent Lake Quadrangle, Nebraska-Garden Co., 7.5 minute series (topographic), USGS, Reston, VA

United States Geological Survey (1986b) Mumper Quadrangle, Nebraska-Garden Co., 7.5 minute series (topographic), USGS, Reston, VA

United States Geological Survey (1986c) Bean Lake Quadrangle, Nebraska-Garden Co., 7.5 minute series (topographic), USGS, Reston, VA

University of Nebraska-Lincoln (2008) Statewide digital data bases for GIS/mapping: configuration of the water table, 1995. http:// snr.unl.edu/data/geographygis/NebrGISwater.asp\#Configuratio nofWaterTable1995. Cited 17 Nov 2008

Van Dam RL, Simmons CT, Hyndman DW, Wood WW (2009) Natural free convection in porous media: first field documentation in groundwater. Geophys Res Lett 36:L11043. doi:10.1029/ 2008GL036906

Walker JF, Krabbenhoft DP (1998) Groundwater and surface-water interactions in riparian and lake-dominated systems. In: Kendall $\mathrm{C}$, McDonnell JJ (eds) Isotope tracers in catchment hydrology. Elsevier, Amsterdam, pp 467-488

Ward SH, Hohmann GW (1988) Electromagnetic theory for geophysical applications. In: Nabighian MN, Corbett JD (eds) Electromagnetic methods in applied geophysics: theory. SEG Monograph 1:131-313

Webb G, Tyler SW, Collord J, Van Zyl D, Halihan T, Turrentine J, Fenstemaker T (2008) Field-scale analysis of flow mechanisms in highly heterogeneous mining media. Vadose Zone J 7:899-908

Wilhite DA, Hubbard KG (1990) Climate. In: Bleed A, Flowerday $\mathrm{C}$ (eds) An atlas of the Sand Hills, Univ. of Nebraska, Conservation \& Survey Division. Resource Atlas 5A:43-56

Won IJ (2003) Small frequency-domain electromagnetic induction sensor: How in the world does a small broadband EMI sensor with little or no source-receiver separation work? The Leading Edge 22:320-322

Won IJ, Keiswetter DA, Fields GRA, Sutton LC (1996) GEM-2: a new multifrequency electromagnetic sensor. J Environ Eng Geophys 1(2):129-137

Wood WW, Sanford WE (1990) Ground-water control of evaporite deposition. Econ Geol 85:1226-1235

Zlotnik AV, Burbach M, Swinehart J, Bennett D, Fritz SC, Loope DB, Olaguera F (2007) Using direct-push methods for aquifer characterization in dune-lake environments of the Nebraska Sand Hills. Environ Eng Geosci 8(3):205-216

Zlotnik VA, Olaguera F, Ong JB (2009) An approach to assessment of flow regimes of groundwater-dominated lakes in arid environments. J Hydrol 371:22-30 